\title{
PEDAGOGICAL GUIDELINES FOR THE CREATION OF ADAPTIVE DIGITAL EDUCATIONAL RESOURCES: A REVIEW OF THE LITERATURE
}

\author{
Hugo Rozo*iD, Miguel Real $(\mathbb{D}$ \\ Universidad de La Sabana (Colombia) \\ *Correspondingauthor: hugoroga@unisabana.edu.co,miguelreos@unisabana.edu.co
}

Received January 2019

Accepted February 2019

\begin{abstract}
The present article constitutes a systematic review of the literature with the objective of identifying the appropriate elements that must be considered when designing and creating adaptive digital educational resources. The methodological process was rigorous and systematic, employing an article search in which the texts related to the object of study were identified, selected, evaluated and analyzed. It is concluded from the analysis of the documentary corpus that the different approaches found configure a roadmap for the conceptualization of what a digital educational resource should be in order to serve as an element that contributes to learning. In this sense, an exemplary model user is proposed that considers experiences, interests and tastes, thus making it possible to strengthen the particularities of students and enhance the learning experience.
\end{abstract}

Keywords - Learning, Documentary analysis, Model user, Adaptive digital educational resources.

\section{To cite this article:}

Rozo, H. \& Real, M. (2019). Pedagogical guidelines for the creation of adaptive digital educational resources: A review of the literature. Journal of Technology and Science Education, 9(3), 308-325. https://doi.org/10.3926/jotse.652

\section{Introduction}

The development of digital educational resources has currently become a relevant teaching and learning strategy; their use has been transformed and enhanced, and they are no longer considered to merely be informative resources, rather they have been positioned as a key element to facilitate knowledge acquisition by students, allowing them to comprehend and interact with the material, according to the interests, learning pace and prior knowledge of each subject (Colchester, Hagras, Alghazzawi \& Aldabbagh, 2017; Okpo, Masthoff, Dennis \& Beacham, 2017).

This is largely due to the possibilities that technology currently provides, such as the topic of adaptive systems, expert systems, automatic learning and intelligent agents, the possibilities and alternatives for which have yet to be explored in education (Michalski, Carbonell \& Mitchell, 2013; Verma, 2018). What is certainly true is that these artificial intelligence techniques mentioned above, while posing challenges during implementation related to costs, infrastructure and development, also present challenges from the pedagogical perspective, as they make the process of creating and designing materials more complex. For 
this reason, educational and instructional designers, content experts and the entire team taking part in the process must consider the possibilities offered by the technologies, in order to make the best possible use of them and present them in such a way that the engineer developers can implement the techniques in the proposed educational materials.

Taking this into account, a gap is observed between what is reported in the literature in journals specialized in engineering, computer science and educational technology (Jain, Gurupur, Schroeder \& Faulkenberry, 2014; Crowe, LaPierre \& Kebritchi, 2017; Siau, 2017; Chassignol, Khoroshavin, Klimova \& Bilyatdinova, 2018) and what is reported in educational journals (Roll \& Wylie, 2016; Baker, 2016; Romiszowski, 2006). It seems as if they addressed two distant moments in time or different topics, since the first scenario presents evidence of the development and implementation of this type of materials described above, in which some elements of artificial intelligence are already integrated, making possible that which was previously impossible. In the second scenario, only some isolated cases are reported, and a call is made to develop this type of materials; hypotheses are made, discussion is proposed. In addition, user models are created, taking into account learning styles, but great advances have yet to be seen. This latter scenario is very similar to what can be seen in most digital educational resources that are found on portals or in resource banks, where some important limitations are evident in terms of deployment or transmitting contents, low levels of usability, the use of a single instructional strategy, and a design focused on the content and not on the various needs of the students.

In this sense, since 2006 and even before, authors like Herrera (2006) have expressed that the necessary conditions must be generated to promote learning, in such a way that all the educational strategies used in the educational materials permit establishing relationships between the new concepts and the previous information the student already has, with the aim of enabling them to build their own knowledge.

In this regard, according to the position taken by Paz, Espinosa, Sánchez and Porlán (2008), an Adaptive Digital Educational Resource (ADER) can be considered to be one that takes into account aspects related to the context of use, content presentation, interface aspects, help and tutorials. Designed with the purpose of providing a flexible environment for students, shifting the focus centered on information and concerned with bringing students to a reflective learning environment, where they must make decisions that will cause them to generate their own learning pace. In the same sense, Ferraro (2006) defines it as that non-sequential resource that presents information in a flexible manner and in such a way that it can be voluntarily manipulated by the student. It should preferably not be provided in textual form, rather using images, sound, animation and video. This would represent an intertextual approach, capable of building knowledge in an evolutionary manner according to the student's capabilities.

Along these lines, it is crucial to consider learning styles whenever the aim of an educational material must be projected towards an interaction that provides for an experience between the learning resource and the student. In this regard, Ferraro (2006) conceives of learning styles as a possible route to achieving this interaction, which meets the specific needs of students and generates stimuli, awakening the students' interest in a certain context. This means that the resource must offer the user a good educational experience, i.e., instructional, contextualized and exploratory.

So far, some succinct arguments have been presented about what an adaptive digital educational resource should be, which will be examined in greater detail later on. Even so, there is evidence of the great concern about this type of resources generating and ensuring learning on behalf of students. For this reason and taking into account that the focus of the investigation was oriented towards identifying the pedagogical elements that must be considered when designing and creating adaptive digital educational resources, which is fairly broad if it is considered that it was approached from the literature in the fields of educational science and computer science, it becomes necessary to pose some secondary questions that would permit maintaining perspective and identify the aforementioned elements. The secondary questions are: How have student needs been identified?, how has the concept of the digital educational resource been constructed? and what is the current discussion on adaptiveness? All were important and were approached through the proposed categories of analysis. 


\section{Methodology}

\subsection{Type of Study}

The present research is based on a systematic review of the literature according to the proposal made by Dane and Fink (2010). The purpose of which is to identify the pedagogical elements that must be taken into account in order to design and create an ADER, in light of what is reported in the literature on the different fields of knowledge, creating a dialog and synergy that contribute to the development of this type of materials through a complete historical state of the art. This means a possibility of discerning and revealing the strengths, weaknesses and problematic areas described in the literature in theory and practice, and identifying some pedagogical orientations that must be considered when creating adaptive educational resources.

According to Pino, García and Piattini (2006), the main purpose of a systematic review of the literature is conducting a sequential and methodical exploration in such a way that makes it possible to detect results pertaining to a topic of interest, beyond than those that can be identified by reviews of humbler dimensions. In doing so, findings that promote new ways of tackling the problem are identified, including the projective use of DER as an opportunity for generating adaptive educational materials that contribute to building knowledge.

\subsection{Procedure}

The method used to conduct the following study is based on the stages presented in Figure 1.

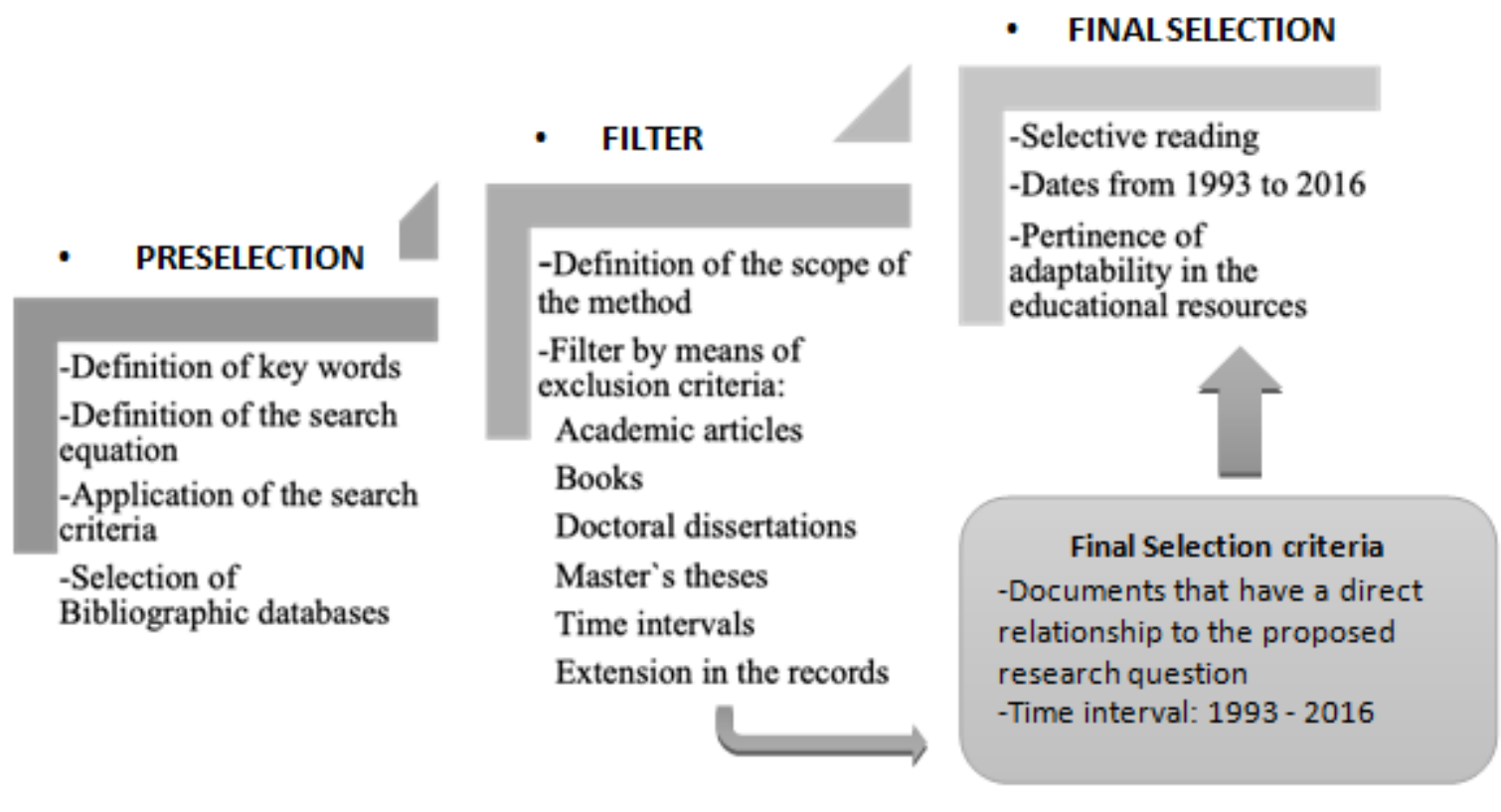

Figure 1. Selection stages

\subsection{Preselection of Information and Filter}

In light of what has been succinctly stated in the previous paragraphs, it is necessary to pedagogically think about systems that are adapted to different student learning styles and that offer different experiences that meet today's educational demands. Here is where adaptive systems demonstrate an advantage and a possibility for instruction, since the system recognizes the characteristics of the user, adapting to their preferences. This is in contrast to what occurs in the "classic" hypermedia, which display the same contents and links to all users (Berlanga, 2006). 
As has been presented until now, the topic of adaptiveness has been considered for decades in different fields of knowledge. This is, however, a topic yet to be explored, in which it will be necessary to present and then agree on the elements that have been addressed in order to be able to articulate them for implementation by the teams developing digital educational materials. For this reason, the present article intends to answer the question, "What elements from a pedagogical perspective must be considered when creating or designing an ADER?" By answering this question, it is hoped to reveal some of the elements that converge and make the development of this type of materials possible.

To conduct the documentary review, we began by formulating a problem that would make it possible to guide the search in the existing literature. After this, a bibliographic inquiry was formulated with the following key words: Adaptive, learning styles, digital educational resources, multimedia and adaptive hypermedia, intelligent tutors, adaptatividad, estilos de aprendizaje, recursos educativos digitales, multimedia e bipermedia adaptativa, tutores inteligentes. These key words arose from terms mentioned in the previous inquiry into the research topic. Likewise, the following bibliographic databases and search engines were selected; they constitute the main sources of information: ProQuest, Dialnet, Scielo and Google Scholar. Once these activities were completed, the search equations were defined according to the pertinence of each of the sources in the results, as shown in Table 1.

Continuing with the process, the respective filters were applied, and the initial sample of 891 documents was reduced to 238 . These were then reviewed through an abstracting process that was performed in the final selection phase.

\begin{tabular}{|l|l|c|}
\hline $\begin{array}{c}\text { Bibliographic } \\
\text { database }\end{array}$ & \multicolumn{1}{|c|}{ Search equation } & $\begin{array}{c}\text { Results } \\
\text { found }\end{array}$ \\
\hline ProQuest & $\begin{array}{l}\text { (Adaptive OR adaptatividad) AND (digital educational resources OR recursos } \\
\text { educativos digitales) AND multimedia AND hypermedia AND (estilos de aprendizaje } \\
\text { OR learning styles) }\end{array}$ & 12 \\
\hline Dialnet & (Adaptive OR adaptatividad) & 5 \\
\hline Scielo & $\begin{array}{l}\text { Adaptatividad AND recursos educativos digitales AND multimedia AND estilos de } \\
\text { aprendizaje }\end{array}$ & 21 \\
\hline Google Scholar & $\begin{array}{l}\text { (Adaptive OR adaptatividad) AND (learning resources OR recursos educativos } \\
\text { digitales) AND multimedia AND hypermedia AND (estilos de aprendizaje) }\end{array}$ & 853 \\
\hline Total: & \multicolumn{1}{|c|}{ And } \\
\hline
\end{tabular}

Table 1. Search equations

\subsection{Final Selection}

During this phase, an extensive reading or abstracting process was conducted, in which the documents that contributed to the formulation of the problem were selected in order to answer the research question, focusing on the title and abstract of the document and in some cases, on other sections, as necessary. 52 selected documents remained following the abstraction process, as identified in Figure 2.

In the case of Google Scholar, it was necessary to stop the abstracting process on page 10, having reviewed a total of 200 texts, as the pertinence and coherence were becoming increasingly lower and the search was becoming more diffuse. In this case, it should be clarified that the initial sample consisted of 238 documents, which were subjected to abstraction. Of these, 52 final documents remained, which were qualitatively analyzed in depth through data analysis categories and a systematic process in the Atlas.Ti software. 

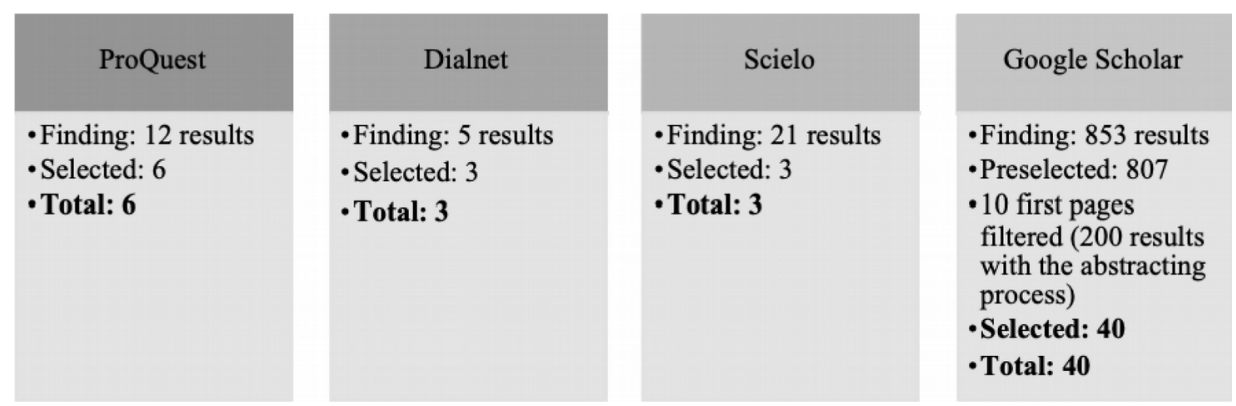

Figure 2. Characteristics of the sample

\section{Discussion and Results}

Once the sample of documents was selected and taking into account the literature review question and the proposed method, priori analysis categories were then established which made it possible to respond to the question and conduct a systematic and coherent analysis of the literature. These categories were: digital educational resource, learning styles, adaptiveness and user model. These matched the search equation and what was reported in the literature. Each category is described in Table 2.

With these categories, a series of iterative in-depth readings were carried out of the documents. Semantic networks were then created with the help of Atlas.Ti for each category. The purpose was to triangulate the sources consulted and to obtain a holistic analysis that is impartial and free of the biases. In this sense, the present section is developed, approaching each of the interrelated proposed categories, guided by the literature review question.

\begin{tabular}{|l|l|}
\hline \multicolumn{1}{|c|}{ Category } & \multicolumn{1}{c|}{ Description } \\
\hline Digital educational resource & Historic conceptualization and different meanings of the concept \\
\hline Adaptiveness & Conceptualization and different meanings of the concept \\
\hline Learning styles & $\begin{array}{l}\text { Construct based on which certain elements of resource adaptiveness have been } \\
\text { developed }\end{array}$ \\
\hline User model & $\begin{array}{l}\text { Items that make up a series of elements intended to define possible patterns of } \\
\text { possible behaviors in students or users }\end{array}$ \\
\hline
\end{tabular}

Table 2. Table of categories

\subsection{Digital Educational Resources (DER)}

As part of the analysis of this category, the different positions and the transition of the concept were examined. These aspects were permeated by elements linked or related to adaptiveness, in light of the research equation, although perhaps not explicitly, but rather intrinsically aimed and oriented by this perspective. In agreement with this, it can be revealed that in 1993, Cano and Justicia presented a model in which students are considered active subjects, capable of deploying a wide variety of conducts that will determine their learning. As a result, it is crucial to generate a resource that meets the needs of the different learning styles, making the learner a relevant variable in the design of a DER. According to this, Camarero, Martín and Herrero (2000) argue that it is important to generate and propose strategies based on self-instruction and self-control, as well as techniques that support attention and internal and external motivation. These ultimately permit the self-regulation of the learning processes, with a positive influence on the academic performance of students.

With a more traditional vision, Pérez, Gutiérrez, López, González and Vadillo (2001) propose that the following aspects must be considered in the design of a DER: establishment of the resource objectives, activities, instructional design and feedback. This means that the objective is to generate in students the need to learn topics they have yet to master, offering an answer in the form of the resource that has been 
created. The limitation arises in that all students are conceived of as a whole, and one single objective is proposed, along with a single trajectory and generic feedback.

The approach above would suppose a limited focus, if the student is considered to have special characteristics that determine their performance and appropriation in the use of educational resources. In response to these peculiarities, Carro, Breda, Castillo and Bajuelos (2002) propose a model in which the user can select the activities to perform, depending on their personal characteristics and the results of their interaction with the resource. Other authors, in turn, focus the conceptualization on topics more closely related to interoperability and technical aspects, such as in the case of Gascueña, FernándezCaballero and González (2005), who propose elements such as self-contained design (in which its own information is present), reutilization (which enables its use in different contexts), metadata (so that its description can be found and that are easily retrievable) and small units (which imply that the resource takes no longer than 15 minutes to complete).

After 2008, a focus is perceived that is centered around meeting the needs of students, but in which each student is conceived of as a unique user, addressing topics of learning personalization (Essalmi, Ayed, Jemni \& Graf, 2015). This is the case of Paz et al. (2008), who clarify that a DER cannot be considered an information object, rather quite the opposite, it must provide a flexible environment in which students make decisions that allow them to build their own knowledge. Likewise, González, Duque and Ovalle (2008) identify the importance of student interaction (as a user) with the material, in order to establish the horizons and the educational projection from the comprehension of the context, so that the learning experience is maximized and made the most of.

In this sense, conceiving of the user as the focus for developing the digital resource generates proposals that correspond to the particular characteristics of the student, causing him or her to play a principal role within the DER. For this to occur, the narrative becomes the tool that allows the learner to appropriate the resource and in turn reinforce his or her own learning. It is for this reason that Lai-Chong and Rust-Kickmeier (2008) suggest that the narrative begins from the selection of characters, that these can be configured and that the same story should allow changes, being both flexible and adaptable, in order to generate interest and "hook" the student, while developing the proposed contents or objectives.

Along these lines, Zapata (2009) mentions that an educational resource should be contemplated as a whole, consisting of auxiliary elements, materials and means destined to promoting learning. Finally, it is important not to lose sight of the objective of the DER, which Cacheiro-González (2011) believes lies in the question of how the instructor proposes tools in the spirit of facilitating curricular development or for the purpose of simplifying the class contents to improve the learning experience. This can stem from anything from hands-on learning encounters to the intention to develop cognitive skills, nurturing constructions and evaluative reflections.

\subsection{Learning Styles}

There are different theories and proposals to addressing learning styles, which is appropriate from the perspective of adaptiveness, considering that most of the user modeling proposals are based on them (Feldman, Monteserin \& Amandi, 2015; Dascalu, Bodea, Moldoveanu, Mohora, Lytras \& de Pablos, 2015; Özyurt \& Özyurt, 2015). This is the starting point for identifying behavioral patterns, rhythms, preferences and interests of students, for the purpose of responding to these needs and particular characteristics of each subject. In accordance with this, a theoretical exploration of the different proposals was carried out, reviewing the points of convergence and the importance they have had in the development of adaptive digital educational materials (Fabregat, Moreno, Amo, Fuertes, González \& Martínez, 2010; Richter \& McPherson, 2012; Zamora-Musa, Vélez, Paez-Logreira, Jesus, Cano-Cano \& Martínez, 2017).

In this sense is the proposal by Cano and Justicia (1993), who believe that the fact that each person follows motivations that nurture comprehension differently, in order to pave the way that facilitates 
learning from the perspective of an education capable of promoting recognition of differences as a pedagogical tool. Peña, Marzo, de La Rosa and Fabregat (2002), in turn, base themselves on the proposal by Price, Dunn and Dunn (1997), which describes a learning style as the way in which a student approaches new and difficult information, deciphering it and retaining it. Furthermore, Cassidy (2004) takes up the proposal by Honey and Mumford (1992), who argue that a learning style is a description of the attitudes and behaviors that determine the individual's preferred method of learning, while Gallego and Martínez (2003) refer to learning styles as those favorite strategies that permit new information to be gathered, interpreted, organized and reconsidered. Finally, Moya, Hernández, Hernández and Cózar (2011) define the term "learning style" as the way in which each person uses his or her own method or strategies to learn, and thus the need is evident to recognize the differences that students have with regard to their learning in relation to others.

The definitions presented above of this category propose two fundamental scenarios in the conceptualization of this. The first scenario refers to learning styles as the capacity for processing and comprehending information by each individual, while the second scenario focuses on the different strategies and ways of organizing information and contents to later be analyzed and related to one another. The truth is that both scenarios are part of the same process, which is learning. It consists of a series of elements that make it complex. What is really important in each of the proposals is that they reveal that not all human beings learn in the same way. There are different ways of approaching knowledge, and these differences create an opportunity that must be taken advantage of or taken into account on a pedagogical level. This thus means that educational processes must respond these peculiarities.

In accordance with this, several proposals have been created, most of which integrate both scenarios. One of these is by Honey and Mumford (1992), as cited by Gallego and Martínez (2003), which groups the styles into four different types, as shown in Table 3.

In addition, other authors propose different learning styles according to individual preferences and access to knowledge. According to the experiential learning theory proposed by Kolb and Kolb (2005), there are four learning styles, which are set out in Table 4.

Using the proposals by Kolb, Honey and Mumford as a basis, when planning a DER, it is important to propose one or more strategies that take into account the characteristics of each student, creating a user model. In this way, experience, participation and interaction by the subject with the resource will enable him or her to approach the knowledge in an appropriate manner and will not force routes or paths that generate distractions or confusion. Likewise, the arrangement and different ways in which the content is structured are important, as are the variety of formats and aspects related to usability and accessibility.

\begin{tabular}{|l|l|l|l|l|}
\hline \multicolumn{1}{|c|}{ Active } & \multicolumn{1}{|c|}{ Reflective } & \multicolumn{1}{|c|}{ Analytic and exhaustive } & \multicolumn{1}{c|}{ Theoretical } & \multicolumn{1}{c|}{ Pragmatic } \\
\hline $\begin{array}{l}\text { Seeks out new } \\
\text { experiences, open- } \\
\text { minded, not at all } \\
\text { skeptical and takes on } \\
\text { new tasks with } \\
\text { enthusiasm. }\end{array}$ & $\begin{array}{l}\text { Prioritizes } \\
\text { reflection over } \\
\text { action, carefully } \\
\text { observes the } \\
\text { different situations } \\
\text { that arise. }\end{array}$ & $\begin{array}{l}\text { Takes his/her time to } \\
\text { analyze the situations that } \\
\text { arise. }\end{array}$ & $\begin{array}{l}\text { Seeks out } \\
\text { rationality and } \\
\text { objectivity, } \\
\text { avoiding } \\
\text { Chabjectiveness and } \\
\text { Thoughtful, conscientious, } \\
\text { ambiguity. }\end{array}$ & $\begin{array}{l}\text { Likes to act } \\
\text { quickly and with } \\
\text { security with those } \\
\text { ideas and projects } \\
\text { that he/she finds } \\
\text { attractive. }\end{array}$ \\
$\begin{array}{l}\text { Characteristics: } \\
\text { Encourager, } \\
\text { improviser, risk-taker } \\
\text { and spontaneous. }\end{array}$ & exhaustive. & $\begin{array}{l}\text { Characteristics: } \\
\text { Methodical, logical, } \\
\text { objective, critical } \\
\text { and structured. }\end{array}$ & $\begin{array}{l}\text { Characteristics: } \\
\text { Experimenter, } \\
\text { practical, direct } \\
\text { and effective. }\end{array}$ \\
\hline
\end{tabular}

Table 3. Honey and Mumford's learning styles 


\begin{tabular}{|c|c|c|c|}
\hline \multicolumn{4}{|c|}{ Learning Styles } \\
\hline Active & Reflective & Theoretical & Pragmatic \\
\hline $\begin{array}{l}\text { Learning is based on the } \\
\text { direct experience of the } \\
\text { person, who is a risk-taker, } \\
\text { spontaneous, a discoverer } \\
\text { and an encourager. }\end{array}$ & $\begin{array}{l}\text { Focused on observation } \\
\text { and information } \\
\text { gathering: analytic, } \\
\text { patient, conscious. }\end{array}$ & $\begin{array}{l}\text { Based on the formation of } \\
\text { concepts from abstraction and } \\
\text { the generation of conclusions: } \\
\text { methodical, critical, structured, } \\
\text { planned, objective. }\end{array}$ & $\begin{array}{l}\text { Draws from } \\
\text { experimentation and search } \\
\text { for practical elements: } \\
\text { realistic, technical, direct } \\
\text { and an experimenter. }\end{array}$ \\
\hline
\end{tabular}

Table 4. Kolb's experiential learning styles

In this way, recognizing the student's interests and managing to reflect them in a way that favors the acquisition of new knowledge becomes a pedagogical challenge, which emerges from the personalization of learning and obviously includes educational resources as key tools within the process. In the words of Gardner (2001), as cited by Fernández (2012), "The great challenge for both the teacher and the student is to find that balance between the degree of challenge an activity presents and the degree of skill the person has who is doing it" (pp. 16).

\subsection{Adaptiveness}

In agreement with what is revealed by the results, it can be quickly concluded that the design of a DER must take into account various aspects, such as the proper presentation of the information and contents, the context of use, help for the student, and the strategy and narrative, among other elements. All these aspects configure a model that is adaptive in construction, in which a flexible and reflexive environment is generated that supports the student's learning pace. Therefore, the present category includes concepts and theories that are articulated according to their proposals and agreement and are not oriented by their historic evolution.

In this sense, Morillo (2016) proposes that adaptive learning suggests the personalization of the learning techniques, which after undergoing a process of identification, seek to meet the specific needs of the student, offering him or her a personalized experience. In accordance with Mérida, Fabregat and Baldiris (2010), the term "adaptiveness" has been used by several authors, who present it as a possibility for digital interaction that lets the user correctly navigate through the contents, where they will find adjustments and variations related to their interest. This results in a feedback process between the system and the user, developing different alternatives capable of optimizing the teaching and learning process.

On the other hand, Brusilovsky (2001) considers those hypertext systems that take into account the user's characteristics to be adaptive hypermedia systems. Their objective is to promote interaction through the peculiarities indicated by the user type. The system must thus recognize and adapt the system contents to the Internet user's profile. Duque and Ovalle (2011) consider adaptiveness to be the system's capacity to dynamically meet the requirements of the user-system interaction, in an attempt to reach the proposed objectives for which it was designed. Brusilovsky and Maybury (2002) propose that adaptive systems (AS) refer to those systems that have the capacity to adjust how they function in response to the goals, tasks, interest and other characteristics of the users or groups of users.

Arteaga and Fabregat (2002), in turn, state that for the creation of an adaptive digital educational material, efforts must be focused on permitting the user to view the information dynamically, with a particular guide directed and oriented towards the interests of the students. According to Prieto (2006), this consists of determining the necessary attributes and metrics for each of the users, in such a way that permits measuring the presence and form of interaction between the student and the DER.

In light of this, some authors, such as Duque, Ovalle, Vicari and Azambuja (2008) and Mérida et al. (2010), take into account Oppermann's user characteristics, which can be divided into two different types: adaptable systems and adaptive systems. Adaptable systems are those that permit the user to change certain system characteristics to adjust their behavior. One way of recognizing these user characteristics, according to Pereira, García and Romero (2003), is through personalization by means of defining the user 
parameters, a list of options that lets the student select his or her characteristics pertaining to how the service operates, selecting preferences from a list of options.

Adaptive systems are those that automatically adapt to the user in light of suppositions made by the system in accordance with the user's needs. In this latter case, the user model is created based on the interaction with the system through its interface, capable of presenting users a series of trends and characteristics that are a reflection of their personality, interests, difficulties, opportunities and learning styles, that ultimately consolidate the resource as their own. In this sense, the challenge consists of determining how to work and present the contents so that they cannot just be considered a series of initial instructions, rather they make it possible to energize the resource throughout its development.

Therefore, in order to consider a resource adaptive, Brusilovsky (1996) establishes five elements that must be considered: knowledge, the objectives, user characteristics, user navigation experience and user preferences. This author also proposes an operating scheme for an adaptive system, as shown in Figure 3 (Brusilovsky \& Maybury, 2002).

The Figure 3 shows how the data related to the user characteristics are collected and how when identified by the adaptive system, they are synthesized into a user model that determines the contents, the navigation and their presentation in the system. A mechanism is devised to regulate information and design adaptive tools that demonstrates a concern for user peculiarities and also question during the process the impact the system has, not only in terms of interaction, but also with regard to the conceptual and pedagogical goals that constitute it as an adaptive digital educational resource that responds to different learning styles.

Within the same scheme, Brusilovsky and Maybury (2002) establish three dynamic elements that come into play in the construction of the user model: contents, navigation and presentation. With regard to the contents, the authors describe the different ways of presenting the contents and of accessing them, taking into account that the information must be dynamic and able to be presented gradually, according to the student's progress and pace. Navigation refers to topics of usability and accessibility that simplify interaction with the system for the user. These two elements make up the last aspect, designated as presentation, which is the way in which the system adapts itself and is presented according to each of the user groups that can be identified, offering a personalized space and generating empathy with the student.

Table 5 shows some of the considerations to keep in mind when setting out to make a resource adaptive. For this purpose, a comparison has been made of elements of the proposals by Brusilovsky (1996), Kobsa (2001) and Karampiperis and Sampson (2005).

As shown in the table, it is important to consider the characteristics of the users, as well as their prior experience, followed by the clarity of the system objectives and the educational experience that we wish to provide. However, there is a factor that so far has not emerged from the data and the proposals, but that is coherent with the proposal and with what has been discussed so far: the topic of feedback, which will be addressed later on. It is understood that the evaluation process must be a formative process that is coherent with the experience of each student.

As a proposal in terms of information management within the resource, adaptiveness generates an advantage by permitting data to be obtained from the student, making the information more flexible and showing a path for implementing the resource. This path must be characterized by showing content in a dynamic manner and leading the student in search of a satisfactory experience that allows him or her to better understand the content offered by the resource. Therefore, the intent here is not merely to obtain a software tool with a series of links or simple changes, rather a complex system that aids and makes it possible for each student to learn. 


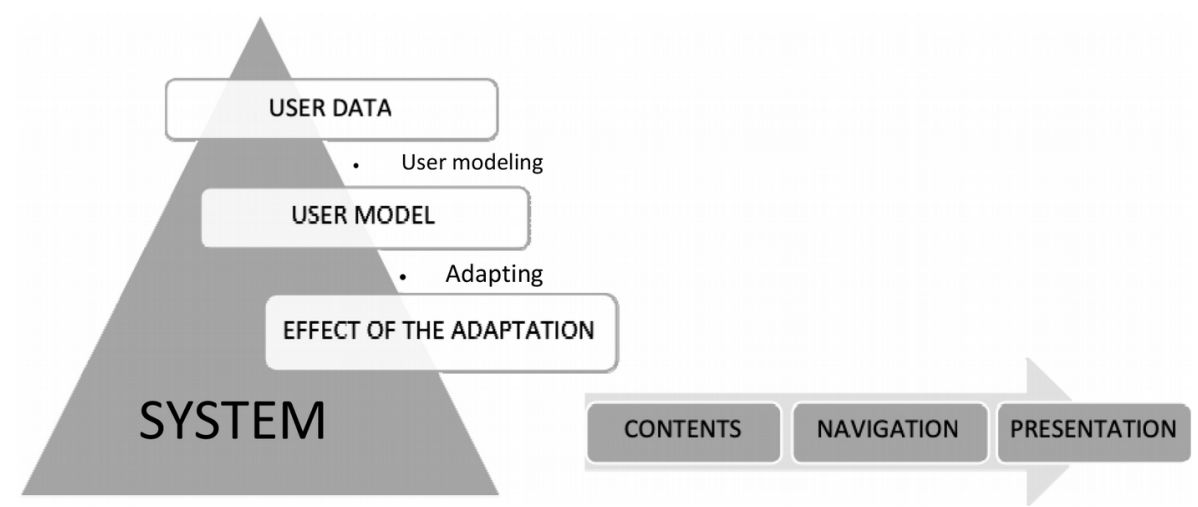

Figure 3. Adaptive systems according to Brusilovsky and Maybury (2002)

\begin{tabular}{|c|c|c|c|}
\hline \multirow[b]{2}{*}{ Elements } & \multicolumn{3}{|c|}{ Author } \\
\hline & Brusilovsky (1996) & Kobsa (2001) & $\begin{array}{l}\text { Karampiperis and } \\
\text { Sampson (2005) }\end{array}$ \\
\hline $\begin{array}{l}\text { Generation of the } \\
\text { user profile }\end{array}$ & $\begin{array}{l}\text { - Knowledge. } \\
\text { - Objectives sought. } \\
\text { - Characteristics related to } \\
\text { the user's experience in } \\
\text { other fields of study. }\end{array}$ & $\begin{array}{l}\text { User data: knowledge of } \\
\text { the topic, skills, } \\
\text { preferences, goals, etc. }\end{array}$ & $\begin{array}{l}\text { Determining factors: } \\
\text { aspects of the learning } \\
\text { experience that will } \\
\text { determine the } \\
\text { adaptation, i.e. what is } \\
\text { the basis for the } \\
\text { adaptation? }\end{array}$ \\
\hline Resource use & $\begin{array}{l}\text { - Navigation experience. } \\
\text { - User preferences. }\end{array}$ & $\begin{array}{l}\text { - Use data: how does the } \\
\text { user interact with the } \\
\text { AHS? }\end{array}$ & $\begin{array}{l}\text { The constituents: } \\
\text { aspects of the } \\
\text { educational experience } \\
\text { that are subject to } \\
\text { adaptation, i.e., what is } \\
\text { going to be adapted? }\end{array}$ \\
\hline Resource feedback & - Does not apply & $\begin{array}{l}\text { Environmental data: } \\
\text { information from the } \\
\text { technical environment of } \\
\text { the user that affects the } \\
\text { functioning of the AHS. }\end{array}$ & $\begin{array}{l}\text { Aspects of the } \\
\text { experience subject to } \\
\text { adaptation and how they } \\
\text { are related to one } \\
\text { another. }\end{array}$ \\
\hline
\end{tabular}

Table 5. Elements considered for the adaptation

\subsection{User Model}

One of the important aspects that has been considered in the previous categories is the creation of a user model that makes it possible to respond to the idiosyncrasies of each subject that interacts with the material. This model will permit collecting information on the characteristics, preferences and needs of each student. In this regard, Berlanga (2006) revisits the proposal by Brusilovsky (2001) in which it is suggested that an adaptive hypermedia system must include a user model where the goals, preferences and knowledge of each individual are defined, in order for the system to use this information throughout the interaction with the user, adapting to his or her needs. According to Mérida et al. (2010), by defining a user model, the system can monitor the user's behavior and thus adapt the presentation of the system to that behavior.

The user model is a definitive element in the design of educational resources. Mendoza (2014) proposes that the modeling of the DER must contemplate those processes that are performed to supply the system with information about the student in such a way that permits it to adapt dynamically and automatically. On the other hand, Duque and Ovalle (2011) explain how an adaptive system must function, understanding that adaptation is based on the consolidation of elements of the user's profile, for the purpose of conforming to the purposes of the system. Erdoğmuş and Koç (2011) suggest that the author of the model must create elements that support learning, permitting the selection of characteristics that 
facilitate the operability of the digital material. In this sense, Vélez (2009) presents the approach used by Brusilovsky and Millán (2007) to a "user model" based on the three questions shown in Figure 4:

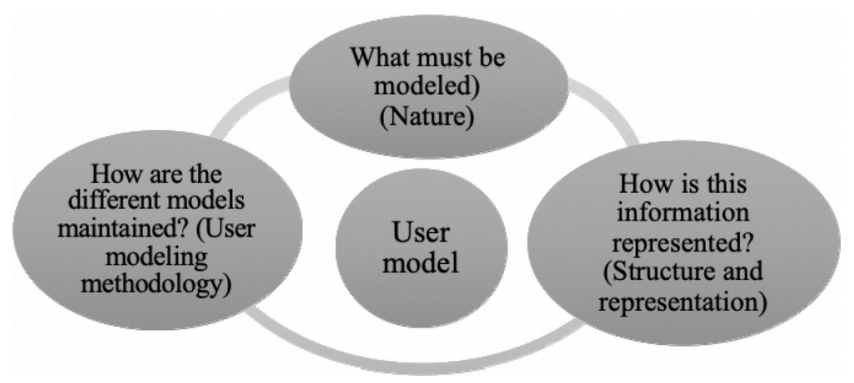

Figure 4. Brusilovsky and Maybury's (2007) proposed user model questions

It is thus important to determine the user model, which will enable the adaptation strategy to be selected, since the system methodology and how the information will be represented are defined here in terms of the content presentation. These learning strategies must be anticipated by continuous guidance that allows the learner to receive personalized feedback within the process.

It is there, in reciprocal information sharing as a fundamental exercise in the construction of educational resources, where the term feedback comes into play, which according to Dempsey and Sales (1993), refers to the constant communication with the student who participates in the instructional practice and the work done through the digital resource. According to this principle, students must be informed after the completion of each process about their performance, with the primary objective of establishing the reinforcement, difficulties and plans for improvement that must be implemented, not only in relation to the disciplinary knowledge, but also in the permanent construction of the resource itself. The DER is thus a work in progress and suggests a technological dynamism in its formulation.

Along these lines, for Dāboliņš and Grundspeņkisis (2013), feedback is important for students as it consolidates the learned material and constantly contrasts the information received. It is for this reason that instructional design must consider factors governing the feedback function and the influence of concepts as an experiential relationship between the subject and learning. It thus becomes necessary to design feedback following the student's intervention, according to the work done and with the purpose of demonstrating the competences attained after performing the activity. Individual student differences can be met, understanding their learning styles, motivation control and prior knowledge. To accomplish this, the resources used must prioritize these aspects through the analysis of the information that is found implicitly in the syllabi, community data and topic objectives, among others. The feedback must clearly show the students the number of mistakes made and the work time invested in completing the activities in order to reveal measurable variables that enable them to recognize the progress made in their learning process and, in turn, to identify a pattern of errors, which would allow the system to learn from these common errors and simplify the instruction or activity.

An agent supporting the feedback, as a facilitator within a DER, is the Virtual Tutor. According to Valverde and Garrido (2005), the tutor process is described as the guidance given by the teacher to the student, seeking comprehension of the contents, the following of instructions to complete the work and the clarification of concerns that arise during the course of the activity. Accordingly, certain aspects must be kept in mind for the projection of a virtual tutor, as set out by Ortega (2007): knowledge of the online educational system, adaptation of the student to the system, facilitating methods and techniques of self-study, developing a sense of institutional identification, promoting the self-learning process and detecting conditions of solitude or isolation related to the periods of time in which students show no activity on the system or are concentrated on completing a single activity. According to Arias, Jiménez and Demetrio (2008), said processes must contain a structure with three important elements, namely: the domain model, in which the knowledge to be taught is integrated; the pedagogical model, in which the 
teacher demonstrates pedagogical knowledge; and the student model, in which the recommended activities will be monitored, in addition to student performance.

According to Conati and Manske (2009), students lack the skills needed to self-regulate their own learning process; for this reason, by including a tutor in the experience, better results can be obtained, since with professional support for the activities, users have better control over the system. Ortega (2007) indicates that one of the important aspects of the tutor is that it encourages relationships to be established between the contents and their professional field; it also organizes activities with defined purposes and promotes reflection and critical analysis. Once the tutor support strategy has been established, according to Martínez (2004) it is important to provide pertinent information on the student's development, allowing the learner to comprehend and integrate their experience. Understanding this as feedback with the objective of generating internalization processes in students that permit boosting their capacities.

According to Ortega (2007), Figure 5 shows some of the competences that a virtual tutor must have:

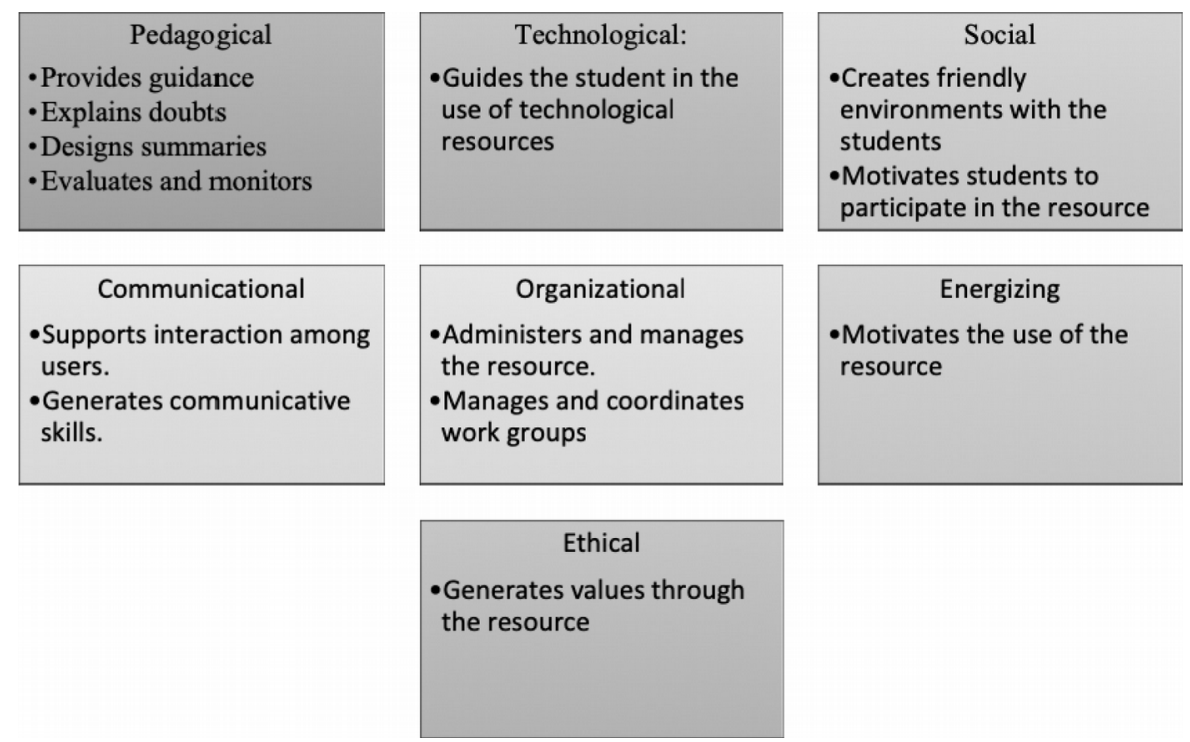

Figure 5. Virtual tutor competences according to Ortega (2007)

Having said this, inferring about the construction of adaptive DER, some considerations are presented on how adaptiveness can be demonstrated, as well as the support for different student learning styles. For this purpose, the goal of consolidating DER as an assertive proposal in education must be set as a creative path capable of elucidating user models that recognize differences in learning. This would mean progress in the analysis of the differences in learning styles and the possibility to create systems capable of personalizing instructions, and beyond this, in questioning a homogenizing educational system that blocks the generation of new strategies for acquiring information and circumvents the creation of knowledge based on the subject's experiential awareness. In this way, it means defining the ways in which learning is configured, and the intentions that can be originated through information. It is understood that knowledge emerges from questioning one's environment and the components that might be presented from the DER. Therefore, the objective must be shared between the inroads made by the technological resources and the increased criticality in the teaching approaches of formal educational spaces. In this regard, Beningni and Marcano (2014) propose three fundamental elements, such as recognizing changes in users according to their interaction with the system, identifying the users' objectives when using the resource, and finally, obtaining information about the users' experience with the system.

\section{Conclusions}

The categories addressed above made it possible to contemplate each of the angles of the subject of study. In this sense, and based on a triangulation of the categories, authors and articles, it was possible to 
identify the pedagogical elements that must be taken into account when designing and creating adaptive digital educational resources.

The first element for creating an adaptive DER is to establish the instructional design, something that is nothing new, but that requires changes in its perception and the way in which it has been done, because if the reason and purpose are observed, it is different and must respond to other elements not previously contemplated. In this sense, the focus must be on selecting the pedagogical strategies or techniques best suited to the individual characteristics of the students in terms of their objectives, learning styles and mastery of the knowledge associated with the DER. According to Berlanga (2006), there are five elements commonly used for adaptation: knowledge, objectives, user characteristics, user experience during navigation and user preferences. Relevant elements when creating the instructional design, which are quite different from the linear focuses and unique navigation paths.

After this, it is necessary to establish a user model that permits the system to recognize the students' characteristics and thus support their individual learning styles, bearing in mind that the topic of learning styles is a current topic of discussion (Kirschner, 2017). This student profile (López, Martínez and Moreno, 2004) can be constructed based on a diagnostic instrument according to the existing theories of learning styles and that is enriched by interactions with the system, errors and recommendations that the users make, as well as the monitoring of behaviors, evolution and management of information within the DER, which will make it possible to recognize the student characteristics (Paredes, 2008; Carro et al., 2002).

After the user profile is defined, it is necessary to find the way to adapt the contents and the way in which they will be presented, thus permitting, as Berlanga (2006) put it, to configure the information and the oaths according to the characteristics of each user, guiding them during the navigation and in the handling of important information within the resource. Part of this necessary feedback so that students retain concepts within the resource can be presented through feedback. As Martínez (2004) states, it is a matter of providing the pertinent information about what the students are developing so that they can internalize it and assume it as part of their personal experience.

So far, the elements presented are pedagogical in nature, and certainly some of them are mediated by technology, but it must be acknowledged that all of the above is possible, taking into account both existing and future technology. It must be clarified and stressed that the intent is not to make systems adaptable, rather adaptive, a differentiation that was formulated in the results. In this sense, adaptive systems require a highly technological component that must be contemplated in the design, and which is the system's capacity to learn from the data and from interactions. In response to this, the system must contemplate a database design that enables it to record and process pertinent information on the behaviors, resource management and results of the students. These data must be managed with the help of artificial intelligence techniques, and more specifically, learning analytics (CITA), in order to process the data and generate help through expert systems, automatic learning and intelligent agents.

For this reason, the existing techniques in the fields of artificial intelligence and computer sciences must be considered to integrate them correctly with these educational materials. The quest is to create artifacts that really support teaching and learning strategies (Peña et al., 2002). Obviously, many of these techniques help solve possible problems, provide solutions and open the door to possibilities that were not previously possible, but that are now a reality (De Castro, García, Romero, De Castro \& Ventura, 2004; Jiménez, 2006).

Likewise, a thorough evaluation should be made of the DER that would make it possible to identify the basic options of usability and learning, as described by Pinto and Gómez (2011), since a resource should not just be "usable" in terms of its design, rather it should present a decisive pedagogical value within the proposal. Once the previous points have been consolidated, the resource must finally strive for and achieve the objective for which it was created, to be a didactic means that is potentially more robust as compared to traditional DERs, using adaptation and user modeling as a tool to respond to student 
learning styles, strengthening the aforementioned process and creating a positive interaction between the user and the system.

\section{Declaration of Conflicting Interests}

The authors declared no potential conflicts of interest with respect to the research, authorship, and/or publication of this article.

\section{Funding}

The authors have received financial support from the Universidad de La Sabana in order to conduct this research.

\section{References}

Arias, S., Jimenéz S., \& Demetrio, O. (2008). Modelo Multi-Agente basado en la Web para Planificación Instruccional y Evaluación Adaptativa en Cursos Virtuales. In IX Congreso Iberoamericano de Informática Educativa RIBIE (1-6). Caracas, Venezuela

Arteaga, C., \& Fabregat, R. (2002). Integración del aprendizaje individual y del colaborativo en un sistema hipermedia adaptativo. JENUI, 2(2), 107-114. Available at: http://lsm.dei.uc.pt/ribie/docfiles/txt2003729191353paper-170.pdf

Baker, R.S. (2016). Stupid tutoring systems, intelligent humans. International Journal of Artificial Intelligence in Education, 26(2), 600-614. https://doi.org/10.1007/s40593-016-0105-0

Beningni, G., \& Marcano, I. (2014). ¿Qué herramientas utilizar para diseñar sistemas hipermedia educativo adaptativos? Revista Espacios, 35(6), 13-18. Available at: http://www.revistaespacios.com/a14v35n06/14350613.html

Berlanga F. (2006). Diseños Intructivos Adaptativos: Formación Personalizada y Reutilizable en Entornos Educativos (Tesis doctoral). Universidad de Salamanca. Available at: http://hdl.handle.net/10366/21858

Brusilovsky, P. (1996). Methods and techniques of adaptive hypermedia. User Modeling and User Adapted Interaction, 6(2-3), 87-129. http://doi.org/10.1007/BF00143964

Brusilovsky, P. (2001). Adaptive Hypermedia. User Modeling and User-Adapted Interaction, 11(1-2), 87-110. https://doi.org/10.1023/A:1011143116306

Brusilovsky, P., \& Maybury, M. (2002). From adaptive hypermedia to the adaptive web. Communications of the ACM, 45(5), 30-33. http://doi.org/10.1145/506218.506239

Brusilovsky, P., \& Millán, E. (2007). User models for adaptive hypermedia and adaptive educational systems. In The adaptive web (pp. 3-53). Springer, Berlin, Heidelberg.

Cacheiro-González, M. (2011). ICT educational resources for information, colaboration and learning. Pixel-Bit: Revista de Medios Y Educación, 39, 69-81. Available at: https://dialnet.unirioja.es/servlet/articulo?codigo=3686204\&

Camarero, F., Martín, F., \& Herrero, J. (2000). Estilos y estrategias de aprendizaje en estudiantes universitarios. Psicothema, 12(4), 615-622. http://doi.org/10.18800/psico.201702.006

Cano, F., \& Justicia, F. (1993). Factores Academicos, estrategias y estilos de aprendizaje. Revista de Psicología General Y Aplicada, 46(1), 89-99. http://doi.org/https://doi.org/10.1007/bf01384091

Carro, R., Breda, A., Castillo, G., \& Bajuelos, A. (2002). Generación de Juegos Educativos Adaptativos. In Aedo, I., Cuevas, P., \& Fernández, C. (Eds.), Actas del III Congreso Internacional de Interacción

Persona-Ordenador (164-171). Granada, España. 
Cassidy, S. (2004). Learning styles: An overview of theories, models, and measures. Educational Psychology, 24(4), 419-444. http://doi.org/10.1080/0144341042000228834

Chassignol, M., Khoroshavin, A., Klimova, A., \& Bilyatdinova, A. (2018). Artificial Intelligence trends in education: a narrative overview. Procedia Computer Science, 136, 16-24.

https://doi.org/10.1016/j.procs.2018.08.233

Colchester, K., Hagras, H., Alghazzawi, D., \& Aldabbagh, G. (2017). A Survey of Artificial Intelligence Techniques Employed for Adaptive Educational Systems within E-Learning Platforms. Journal of Artificial Intelligence and Soft Computing Research, 7(1), 47-64. https:/ /doi.org/10.1515/jaiscr-2017-0004

Conati, C., \& Manske, M. (2009). Adaptive feedback in an educational game for number factorization. In Frontiers in Artificial Intelligence and Applications (Vol. 200, 581-583). Amsterdam: IOS Press. http://doi.org/10.3233/978-1-60750-028-5-581

Crowe, D., LaPierre, M., \& Kebritchi, M. (2017). Knowledge Based Artificial Augmentation Intelligence Technology: Next Step in Academic Instructional Tools for Distance Learning. TechTrends, 61(5), 494-506. https://doi.org/10.1007/s11528-017-0210-4

Dābolinšs, J., \& Grundspeņķis, J. (2013). The Role of Feedback in Intelligent Tutoring System. Applied Computer Systems, 14(1), 88-93. https://doi.org/10.2478/acss-2013-0011

Dane, F., \& Fink, A. (2010). Evaluating Research: Methodology for People Who Need to Read Research + Conducting Research Literature Reviews: from the Internet to Paper (3rd ed.). Sage Publications.

Dascalu, M.I., Bodea, C.N., Moldoveanu, A., Mohora, A., Lytras, M., \& de Pablos, P.O. (2015). A recommender agent based on learning styles for better virtual collaborative learning experiences. Computers in Human Behavior, 45, 243-253. https:/ / doi.org/10.1016/j.chb.2014.12.027

De Castro, C., García, E., Romero, C., De Castro, A., \& Ventura, S. (2004). Herramienta autor indesahc para la creación de cursos hipermedia adaptativos. Revista Latinoamericana de Tecnología Educativa, 3(1), 349-368. Available at: http://dialnet.unirioja.es/servlet/articulo?codigo=1067971

Dempsey, J., \& Sales, G. (1993). Interactive instruction and feedback (1st ed.). New Jersey: Educational Technology.

Duque, N., \& Ovalle, D. (2011). Artificial Intelligence Planning Techniques For Adaptive Virtual Course Construction. Dyna, 78(170), 70-78. Available at: http://dx.doi.org/10.15446/dyna.v78n170.29389

Duque, N., Ovalle, D., Vicari, R., \& Azambuja, R. (2008). Modelo inteligente generico para adaptatividad de cursos virtuales. RENOTE: Revista Novas Tecnologias Na Educação, 6(1), 1-10.

Erdoğmuş, Ş., \& Koç, E. (2011). Using kansei engineering to improve the physical environment of the classroom. The New Educational Review, 23(1), 245-253.

Essalmi, F., Ayed, L.J.B., Jemni, M., \& Graf, S. (2015). Generalized metrics for the analysis of E-learning personalization strategies. Computers in Human Behavior, 48, 310-322.

https://doi.org/10.1016/j.chb.2014.12.050

Fabregat, R., Moreno, D., Amo, F., Fuertes, J., González, Á., \& Martínez, L. (2010). Estándares para e-learning adaptativo y accesible. RIED. Revista iberoamericana de educación a distancia, 13(2), 45-71.

Feldman, J., Monteserin, A., \& Amandi, A. (2015). Automatic detection of learning styles: state of the art. Artificial Intelligence Review, 44(2), 157-186. https:/ / doi.org/10.1007/s10462-014-9422-6

Fernández, F. (2012). Aprender a aprender en educación compensatoria: diseño e implementación de un programa centrado en estrategias de pensamiento en educación primaria y educación secundaria (Tesis de grado). Universidad de Valladolid. Valladolid, España. 
Ferraro, M. (2006). METHADIS: Metodología para el diseño de Sistemas Hipermedia Adaptativos para el aprendizaje, basada en Estilos de Aprendizaje y Estilos Cognitivos (Tesis doctoral). Universiadad de Salamanca. Salamanca, España.

Gallego, A., \& Martínez, E. (2003). Estilos de aprendizaje y e-learning. Hacia un mayor rendimiento académico. RED. Revista de Educación a Distancia, 7, 1-10.

Gardner, H. (2001). Mentes flexibles: El arte y la ciencia de saber cambiar nuestra opinión y la de los demás. Madrid, España: Paidos.

Gascueña, J., Fernández-Caballero, A., \& González, P. (2005). Ontologías del modelo del alumno y del modelo del dominio en sistemas de aprendizaje adaptativos y colaborativos. Castilla, España.

González, H., Duque, N., \& Ovalle, D. (2008). Modelo del estudiante para sistemas adaptativos de educación virtual. Revista Avances En Sistemas E Informática, 5(1), 1657-7663. Available at: https://revistas.unal.edu.co/index.php/avances/article/view/9987

Herrera, M. (2006). Consideraciones para el diseño didáctico de ambientes virtuales de aprendizaje: una propuesta basada en las funciones cognitivas del aprendizaje. Revista Iberoamericana de Educación, 38, 2.

Honey, P. \& Mumford, A. (1992). The manual of learning styles (3rd ed.). Maidenhead: Peter Honey Publications.

Jain, G.P., Gurupur, V.P., Schroeder, J.L., \& Faulkenberry, E.D. (2014). Artificial intelligence-based student learning evaluation: a concept map-based approach for analyzing a student's understanding of a topic. IEEE Transactions on Learning Technologies, 7(3), 267-279. https://doi.org/10.1109/TLT.2014.2330297

Jiménez, J. (2006). Un Modelo de Planificación Instruccional usando Razonamiento Basado en Casos en Sistemas Multi-Agente para entornos integrados de Sistemas Tutoriales Inteligentes y Ambientes Colaborativos de Aprendiraje (Tesis doctoral). Universidad Nacional de Colombia.

Karampiperis, P., \& Sampson, D. (2005). Adaptive Learning Resources Sequencing in Educational Hypermedia Systems. Journal of Educational Technology \& Society, 8(4), 128-147. Available at: http://www.jstor.org/stable/jeductechsoci.8.4.128

Kirschner, P.A. (2017). Stop propagating the learning styles myth. Computers \& Education, 106, 166-171.

Kobsa, A. (2001). Generic User Modeling Systems. User Modeling and User-Adapted Interaction, 11(1), 49-63. http://doi.org/10.1023/A:1011187500863

Kolb, A., \& Kolb, D. (2005). Learning Styles and Learning Spaces: Enhancing Experiential Learning in Higher Education. Academy of Management Learning \& Education, 4(2), 193-212. Available at: http://www.jstor.org/stable/40214287 https://doi.org/10.5465/amle.2005.17268566

Lai-Chong, E., \& Rust-Kickmeier, M. (2008). 80 Days: Immersive Digital Educational Games with Adaptive Storytelling. In Klamma, R., Sharda, N., Fernández-Manjón, B., \& Kosch, \& Spaniol, M. (Eds.), Proceedings of the First International Workshop on Story-Telling and Educational Games (STEG'08) (1-7).

Maastricht, Netherlands.: CEUR Workshop Proceedings.

López, J., Martínez, I., \& Moreno, P. (2004). Desarrollo de un sistema e-learning basado en estándares IMS. Madrid, España.

Martínez, J. (2004). El papel del tutor en el aprendizaje virtual. Barcelona, España. Available at: http://www.uoc.edu/dt/20383/20383.pdf

Mendoza, M. (2014). Modelos de Usuario y Sistemas Adaptativos de Aprendizaje. In Primer Congreso Internacional de Investigación en Ingeniería de Sistemas. CIIIS (206-213). Tunja, Colombia: REDIS: Red de Decanos y Directores de Ingenerías de Sistemas y Afines. 
Mérida, D., Fabregat, R., \& Baldiris, S. (2010). Sistemas heterogéneos adaptativos basados en el contexto. Revista Iberoamericana de Educacióon a Distancia (RIED), 13(2), 73-105.

Michalski, R.S., Carbonell, J.G., \& Mitchell, T.M. (Eds.) (2013). Macbine learning: An artificial intelligence approach. Springer Science \& Business Media.

Morillo, M. (2016). Aprendizaje adaptativo (Tesis máster). Universidad de Valladolid. Valladolid, España.

Moya, M., Hernández, J., Hernández, J., \& Cózar, R. (2011). Analisis de los estilos de aprendizajey las TIC en la formacion del alumnado universitario a traves del cuestionario de reatic. Revista de Investigación Educativa, 29(1), 137-156. Available at: http://www.redalyc.org/pdf/2833/283322813008.pdf

Okpo, J., Masthoff, J., Dennis, M., \& Beacham, N. (2017). Conceptualizing a framework for Adaptive Exercise Selection with Personality as a major Learner characteristic. In Adjunct Publication of the 25th Conference on User Modeling, Adaptation and Personalization (293-298). https://doi.org/10.1145/3099023.3099078

Ortega, I. (2007). El tutor virtual: aportaciones a los nuevos entornos de aprendizaje. Revista Electrónica Teoría de la Educación: Educación y Cultura en la Sociedad de la Información, 8(2), 100-115.

Özyurt, Ö., \& Özyurt, H. (2015). Learning style based individualized adaptive e-learning environments: Content analysis of the articles published from 2005 to 2014. Computers in Human Behavior, 52, 349-358. https://doi.org/10.1016/j.chb.2015.06.020

Paredes, P. (2008). Una propuesta de incorporacion de los estilos de aprendizaje a los modelos de usuario en sistemas de enseñanza adaptivos. Universidad Autónoma de Madrid. Available at: http://arantxa.ii.uam.es/ pparedes/tesis.pdf

Paz, M., Espinosa, P., Sánchez, F., \& Porlán, I. (2008). Producción De Material Didáctico: Los Objetos De Aprendizaje (the Production of Educational Materials: Learning Objects). RIED, 11(1), 81-105.

Peña, C., Marzo, J., de la Rosa, J.L., \& Fabregat, R. (2002). Un sistema de tutoría inteligente adaptativo considerando estilos de aprendiraje; A smart adaptive tutoring system considering learning styles. Colombia, South America: Universidad Industrial de Santander. Available at: http://revistas.uis.edu.co/index.php/revistauisingenierias/article/view/2508

Pereira, R., Garcia, F., \& Romero, L. (2003). Perfiles de usuarios para la adaptatividad de interfaces web. In Frías, A., \& Travieso, C. (Eds.), Actas del IV Coloquio Internacional de Ciencias de la Documentación y VI Congreso del Capitulo Español de ISKO (427-437). Salamanca, España: Ediciones Universidad de Salamanca. http://doi.org/10.13140/RG.2.1.2543.6647

Pérez, T., Gutiérrez, J., López, R., Gonzalez, A., \& Vadillo, J. (2001). Hipermedia, Adaptación, Constructivismo e Instructivismo. Revista Iberoamericana de Inteligencia Artificial, 5(12), 29-38. http://doi.org/10.4114/ia.v5i12.705

Pino, F., García, F., \& Piattini, M. (2006). Revisión sistemática de mejora de procesos software en micro, pequeñas y medianas empresas. Revista Espa Nola de Innovación Calidad E Ingeniería Del Software REICIS, 2(1), 6-23.

Pinto, M., \& Gómez, C. (2011). Propuesta de criterios e indicadores internacionales para la evaluación de los recursos educativos electrónicos. Ibersid, 5(1), 81-87. https://doi.org/10.19030/iber.v10i9.5629

Price, G., Dunn, R. \& Dunn, K. (1997). Learning style inventory (LSI): an inventory for the identification of how individuals in grades 3 through 12 prefer to learn. Lawrence, KS: Price Systems.

Prieto, M. (2006). METHADIS : metodología para el diseño de sistemas hipermedia adaptativos para el aprendizaje, basada en estilos de aprendiraje y estilos cognitivos (Tesis doctoral). Universidad de Salamanca. Salamanca, España. 
Richter, T., \& McPherson, M. (2012). Open educational resources: education for the world? Distance education, 33(2), 201-219. https://doi.org/10.1080/01587919.2012.692068

Roll, I., \& Wylie, R. (2016). Evolution and revolution in artificial intelligence in education. International Journal of Artificial Intelligence in Education, 26(2), 582-599. https://doi.org/10.1007/s40593-016-0110-3

Romiszowski, A.J. (2006). Artificial Intelligence and Expert Systems in Education: Potential Promise or Threat to Teachers? Education Media International, 24(2), 96-104.

Siau, K. (2017). Impact of Artificial Intelligence, Robotics, and Automation on Higher Education. Twenty-third Americas Conference on Information Systems. Boston.

Valverde, J., \& Garrido, M. (2005). La función tutorial en entornos virtuales de aprendizaje: comunicación y comunidad. Revista Lationoamerica de Tecnología Educativa, 4(1), 153-167. Available at: http://dehesa.unex.es/bitstream/handle/10662/1472/1695-288X 41 153.pdf?sequence=1

Vélez, J. (2009). Entorno de aprendizaje virtual adaptativo soportado por un modelo de usuario integral (Tesis doctoral). Universidad de Girona. Girona, España.

Verma, M. (2018). Artificial intelligence and its scope in different areas with special reference to the field of education. Artificial Intelligence, 3(1), 5-10.

Zamora-Musa, R., Velez, J., Paez-Logreira, H., Jesus, C., Cano-Cano, C., \& Martínez, O. (2017). Implementación de un recurso educativo abierto a través del modelo del diseño universal para el aprendizaje teniendo en cuenta evaluación de competencias y las necesidades individuales de los estudiantes. Revista Espacios, 38(05).

Zapata, M. (2009). Objetos de aprendizaje generativos, competencias individuales, agrupamientos de competencias y adaptatividad. RED Revista de Educación a Distancia, IX, 1-32.

Published by OmniaScience (www.omniascience.com)

Journal of Technology and Science Education, 2019 (www.jotse.org)

\section{(c) (i) (8)}

Article's contents are provided on an Attribution-Non Commercial 4.0 Creative commons International License. Readers are allowed to copy, distribute and communicate article's contents, provided the author's and JOTSE journal's names are included. It must not be used for commercial purposes. To see the complete licence contents, please visit https://creativecommons.org/licenses/by-nc/4.0/. 